\title{
Religious Pages in the Palestinian Journalism Analytic Study on Felesteen Daily Newspaper
}

\author{
Wael Abdelrazak Almanama* \\ Press and Media Department, The Islamic University, Gaza \\ *Corresponding Author: Wael Abdelrazak Almanama, Press and Media Department, The Islamic \\ University, Gaza
}

\begin{abstract}
The press is one of the most important printed media because of its influence and wide spread among large sectors of society. It becomes more important if we know that the most important newspaper audience is the educated and intelligentsia, whose viewpoints are a top priority for the rest of society.
\end{abstract}

The importance of newspapers in the Arab and Islamic countries is to devote specialized religious pages dealing with various issues of the Islamic religion, and to address the problems of Muslims daily, and respond to their questions and referendums.

Therefore, the researcher started studying the religious pages specialized in the Palestinian daily newspapers. A sample of these newspapers was taken in the Palestine daily newspaper, which is especially published in the Gaza Strip.

This study is descriptive in nature. The researcher used the survey method, in which content analysis is used in order to come up with the results that serve the newspaper's staff and the media workers.

\section{INTRODUCTION}

Journalism is one of the most important printed media due to its influence and wide spread among large segments of the society. It gets more important when we know that the most important newspapers audience is the educated and intellectual class that represents the ideal opinion for the rest of the society.

Because of this importance, newspapers in the Arab and Islamic devoted certain religious pages dealing with various Islamic issues to address the daily problems of Muslims and to respond to their questions and referendums.

Therefore, the researcher started studying the specialized religious pages in the Palestinian daily newspapers, so a sample from Felesteen daily newspaper which is especially published in the Gaza Strip was taken.

Several studies have been conducted on various similar issues such as:

1. Study entitled "Religious Pages in Saudi Newspapers and Magazines" (Sharif, 2018)

2. Study entitled "Specialized Religious Journalism in the Arab World" (Al-Dalu, 2017)

3. Study entitled "The Stance of the Daily Newspapers on the Issues of Religious Thought" (Hijab, 2017)

This study comes to know the general features of the form and content of the specialized religious pages in the Palestinian daily press. The researcher took a sample representing the Palestine newspaper. Although it agreed with the previous studies in terms of the type of study and methodology, it differs in the medium since the researcher did not find any study dealing with the same subject and the same newspaper.

The researcher also studied a random sample of five versions of Felesteen daily newspaper to help determine the problem of the study and the categories of analysis, whether content or form.

\section{STUdy PROBLeM}

The problem of the study can be identified in how Felesteen daily newspaper published in the Palestinian territories and its headquarter is in Gaza addresses the specialized religious pages in terms 
of space, the sources which it relied on, the types of issues covered in the coverage, the press arts used, and the fixed position of such pages in addition to the typographic elements used in the treatment.

\subsection{Importance of the Study}

The importance of the study arises from the fact that it highlights the treatment of Felesteen daily newspaper for the religious pages. The researcher believes that the study's subject will contribute to enriching the university and scientific library. It will be useful for the scientific research institutions in the academic studies, for the students of media colleges, and those who are interested in print media. The researcher hopes that this study will open the door for students and researchers to go more in the problem of study since it is conducted for the first time.

\subsection{Study Questions}

This study seeks to answer a number of questions:

- What is the extent to which Felesteen daily newspaper is interested in the specialized religious issues?

- What types of issues did the study newpaper focus on?

- What sources did the newspaper rely on?

- What are the journalistic arts used to deal with religious issues?

- What are the elements of highlighting used by the study newspaper in dealing with religious subjects?

- How stable is the publication of religious pages in Felesteen daily newspaper?

\subsection{The Theoretical Framework of the Stud}

The study relied on the prioritization theory which assumes that the media cannot provide all the issues occurring in society. Rather, the directors select some of the topics that are focused on to gradually draw people's attention and make them aware and think about them. Thus, these subjects represent a relatively greater importance to the public than subjects not presented by the media. The researcher chose this theory to study the religious topics that the study newspaper focuses on and to identify the most important religious issues that the study newspaper places on its agenda (Makkawi, 2006: 228)

\subsection{Type of Study, Methodology and Tools}

This study is part of the descriptive researches that "focus on describing the nature and characteristics of a particular society, situation, group or individual, and the frequency of occurrence of different phenomena. It's used in the intermediate stage of scientific knowledge in different majors" (Hussein, 1976: 114). In this type of researches, the researcher used the survey method as it is a systematic scientific effort that helps to describe the phenomenon by collecting information and observations about it, leading to a realistic picture as close as possible (Hussein, 1976: 127). Through the survey methodology, the content analysis method was used to provide a systematic description of what is presented in Felesteen daily newspaper on specialized religious issues and cases.

\subsection{Study Tool}

It is the form of content analysis that the researcher prepared and defined its categories according to the exploratory study carried out on five issues of the study newspaper.

\section{Analysis Categories}

"A group of classifications or factions that the researcher prepares according to the content and its kind and the purpose of the analysis to be used to describe this content and classify it with the highest possible degree of objectivity and comprehensiveness, allowing for analysis and extraction of results in an easy and accessible manner" (Hussein, 1983: 88). They are two types:

\subsection{Subject Categories - What is Said}

It included the following two categories: 


\subsubsection{Category of Cases}

It includes the following subcategories

- Provisions and Fatwas: It is the issues related to the provisions of the Shariah and fatwas on various jurisprudential issues.

- Acts: It includes the topics that talked about Islamic worships and their hypothesis and how to perform them optimally, such as prayer, fasting, Zakat, pilgrimage and others.

- Transactions: It is all the legitimate transactions identified by the jurist to regulate the lives of Muslims.

- Islamic Call: It means the topics that dealt with the call to God and its methods and importance and the command of good and forbidding evil.

- Islamic Thought: This category includes the topics of Islamic thought, Islamic movements, intellectual invasion and ways to address it, and positivist ideas and how to deal with Islam.

- Other: Issues that have received a low percentage of coverage and not previously mentioned such as news of minorities and Muslim communities, important Islamic dates and events, and others.

\subsubsection{Source Category}

It is identifying the sources of religious subjects in the study newspaper and includes the following subcategories:

- Book: They are the owners of opinion and analysis who write in the newspapers, whether they are from the same state or from outside.

- Correspondent: "The journalist appointed by the newspaper to follow events outside the city where the newspaper is published" (Shalabi, 1988: 71.)

- Without a Source: It means the religious subjects published without reference to their source.

- Delegate: "A journalist appointed or specialized by the newspaper to follow events in a particular sector, body, institution, ministry or public facility within the same city where the newspaper is published" (Shalaby, 1988: 71.)

- News Agencies: news agencies that collect news and distribute it to subscribers, whether they are local, regional or international

\subsection{Categories of Form - How was it Said}

This category relates to the way in which the content of the information material was presented and through which its meaning was transmitted. It includes the following subcategories:

\subsubsection{The Form of Writing Press}

It means the format or journalistic art in which the information material has been developed and it includes the following subcategories:

- The Press Release: "It is the accurate and honest information that describes and explains an incident involving a certain category or group that you know for the first time." (Shelby, 1988:51)

- The Press Article: "is a topic of an average length written for publication in the newspapers and it addresses a particular subject in a simplified and concise way; the writer must adhere to the limits of this subject" (Abu Zeid, 1990: 177).

- The Press Report: "It is an art that falls between the news and the investigation. It does not include all the main aspects of the event. It can absorb the description of time, place and circumstances associated with the event and it allows the personal views of the editor to be highlighted" (Abu Zeid, 1990: 133).

- Press Talk: "It is an art based on the dialogue between the journalist and the figure or several figures in order to get news or new information, explain a certain point of view, or portray funny or entertaining positions in the life of the personality" (Aquarius, 1995: 9). 
- Investigative Journalism: "It is a survey of facts, events with all persons involved in these events, factors affecting and judging them in order to provide appropriate solutions to the problem, which is addressed by the investigation. Hence the investigation is characterized as in-depth research into the problem. It makes the reader solve the problem "(Abu Zeid, 1990: 93.)

\subsubsection{Area Category}

The measurement of the area allocated by the newspapers to the content, measured by the centimeter column, and it can be used to know the interest of the newspaper religious issues.

\subsubsection{Position Stability Category}

A group that is interested in knowing the stability of the site of the specialized religious pages on the pages of the study newspaper.

\subsubsection{Category of Topographic Elements}

It refers to the printing process of the media material. It is used to inform the reader of the importance of the subject and highlight it. It includes the following subcategories:

- Images: It means the presence of images accompanying the subject to identify the importance given by the newspaper to the content, whether they are news images or personal or explanatory or otherwise.

- Colors: It means the introduction of colors on the subject to highlight and give it more importance, whether they are the colors of the content, the titles, pictures or drawings.

- Grounds: It means the introduction of a gray ground or other ground shapes to distinguish the subject from other areas on the page

- Drawings: they mean the cartoons or illustrations accompanying the subject.

- Headings: It means identifying the type of addresses used to highlight religious topics. There are seven types of titles: (Aldalo B, 1995: 82-84).

$>$ The Main Title (The Link): It is the top of the first page and exists on the page display.

$>$ Broad Address: It is published on the internal pages display.

$>$ Extended Title: It is an address that is longer than a column and does not reach the width of the page.

$>$ Vertical Title: It is the title that spreads on one column only.

$>$ Secondary Address: The title which follows the main, broad or extended title.

$>$ Preamble: It is the one that paves the way for the wide or extended address and is usually published before any of them on a smaller scale.

$>$ Subheadings (Paragraphs): They are intervals between the paragraphs of the subject which guide the reader to the information and opinions, encourage reading, and give the subject and the page a beautiful form.

- Frames: It means putting the subject in a frame to highlight other subjects on the same page.

\section{SocieTY AND STUdY SAMPLE}

The study community represents the various topics and religious issues published in the study newspaper during the period of time specified for the research, the study subject. The sample of the study are all the issues punlished by Felesteen daily newspaper during 2018, and it was a regular random sample of three-class. Based on reconnaissance and questioning the religious pages official in the newspaper, it was found that religious pages are issued on Friday by two pages on a regular basis. Another page is published in the middle of the week irregularly. It is sometimes published on Monday and sometimes on Sunday or Wednesday, so the researcher decided to choose the issues published on the days of the collection as a sample of the study due to the regularity of the issuing and issuing two religious pages on Friday. The first issue was chosen randomly on Friday 5/1/2018. Two were excluded and the third was taken until the end of the study period, which is 2018. 
This means that the size of the sample of the study is eighteen issues of Felesteen daily newspaper

\subsection{Analysis Units}

They are units which the researcher intends to use. They show the recurrence of the phenomenon of the field of research, and the researcher will resort to use the natural unit of the information material (news - article - talk ...) as a unit of analysis.

\subsection{Measuring Unit}

The subject was selected as a unit of analysis by which the enumeration and measurement are carried out according to the purposes of the analysis and the nature of the research.

\subsection{Method of Counting and Measurement}

It is the systematic quantitative registration of the content modules, classes and variables. It enables you to rebuild content in the form of digits, and it helps to reach quantitative results which contribute to the interpretation and reasoning and the achievement of the objectives of the study (Abdul Hamid, 1983: 181) The method of counting and measurement used in this study is The frequency in which the classes or units appear in addition to the space using the centimeter column.

\subsection{Division of Study}

The study is divided into three sections. The first section includes the methodological procedures for the study. The second part includes the results of the analytical study. Finally, the third topic included discussing the results and recommendations.

\section{RESUlts OF THE ANALYTICAL STUDY}

The researcher in this section deals with the results of the analytical study in six categories divided into topic categories - what was said - it includes the subject category and source category, and then figure categories - how it was said - it includes space class, a class journalist art, site stability class which is under analysis, and the used Altibograveh elements category.

First: The Interest of the Study Newspaper in Specialized Religious Topics

The study aims to identify the size of the area allocated by Felsteen daily newspaper for religious topics and issues, and its proportion of the size of the total area of the sample of the study in order to identify the extent of interest of the newspaper in the mentioned subjects.

Table1: It shows the size of the area allocated by the study newspaper for religious subjects compared with the size of the total space of the sample

\begin{tabular}{|l|l|}
\hline 71280 & The total space of the study \\
\hline 4336 & space of Religious Subjects \\
\hline 6.08 & The size of the religious subjects of the sample space \\
\hline
\end{tabular}

By studying the data of the previous table, it is clear that the area of religious topics and issues reached $4336 \mathrm{~cm} / \mathrm{p}$ with $6.08 \%$ of the total sample sample in felesteen daily newspaper.

Second: Religious Topics and Issues in the Study Newspaper

The following table shows the religious issues and topics in the study paper and the degree of interest in each category.

Table2: It explains the frequency and proportions of religious issues and topics in the study newspaper

\begin{tabular}{|l|l|l|}
\hline$\%$ & $\mathrm{P}$ & Topic \\
\hline 33.3 & 33 & Rulings and Fatwas \\
\hline 18.2 & 18 & The Islamic Call \\
\hline 16.2 & 16 & worships \\
\hline 15.2 & 15 & Islamic Thought \\
\hline 10.1 & 10 & Transactions \\
\hline 7 & 7 & Other \\
\hline 100 & 99 & total \\
\hline
\end{tabular}


The analyzing of the data of the previous table shows that the category of judgments and advisory opinions ranked first in the study newspaper by $33.3 \%$ of the total cases, and it followed by the Islamic call by $18.2 \%$, then the worship by $16.2 \%$, the Islamic thought by $15.2 \%(10.1 \%)$, and finally, other categories such as the Islamic world news, the news of Muslim communities and minorities in the West, and important Islamic events and dates (7\%)

Third: Sources of Religious Subjects in the Study Newspaper

The following table shows the sources on which the study newspaper relied to cover religious topics and issues.

Table3: Shows the frequency and proportions of the sources of religious subjects in the study newspaper

\begin{tabular}{|l|l|l|}
\hline$\%$ & $\mathrm{P}$ & Source \\
\hline 58.6 & 58 & Book \\
\hline 30.3 & 30 & Delegate \\
\hline 8.1 & 8 & sourceless \\
\hline 2 & 2 & Reporter \\
\hline 1 & 1 & agencies \\
\hline 100 & 99 & Total \\
\hline
\end{tabular}

By studying the data of the previous table, it is clear that the book category ranked first among the sources on which the study newspaper was based when dealing with religious subjects and received $58.6 \%$ of the total sources in the newspaper, followed by the delegate by $30.3 \%(8.1 \%)$, followed by the reporter $(2 \%)$ and finally the agencies accounted for only $(1 \%)$.

Fourth: Press Forms Used in the Presentation of Religious Subjects in the Newspaper

The following table shows the journalistic forms and arts used in presenting religious issues and topics in the study newspaper.

Table4: It shows the frequency and proportions of press forms used in presenting religious issues in the study paper

\begin{tabular}{|l|l|l|}
\hline$\%$ & $\mathrm{p}$ & Press forms \\
\hline 54.5 & 54 & Press Articles \\
\hline 28.3 & 28 & Press Reports \\
\hline 8.1 & 8 & Press Investigation \\
\hline 7.1 & 7 & Journalist interview \\
\hline 2 & 2 & Press Release \\
\hline 100 & 99 & Total \\
\hline
\end{tabular}

In the previous table, it is clear that the press article ranked first with $54.5 \%$ of the press formats on which the newspaper relied, followed by the press report (28.3\%), the press investigation (8.1\%), the journalist interviews (7.1\%). Finally, the news came at (2\%)

Fifth: The Stability of the Site of the Published Religious Issues in the Study Newspaper

The following table shows the commitment of the study newspaper to publish specialized religious pages on the same pages.

Table5: It shows the frequency and percentages of the stability of the site of published religious issues in the study newspaper

\begin{tabular}{|l|l|l|}
\hline$\%$ & $\mathrm{p}$ & Publishing site \\
\hline 88.9 & 88 & Fixed \\
\hline 11.1 & 11 & Not fixed \\
\hline 100 & 99 & Total \\
\hline
\end{tabular}

By studying the data of the previous table, it is clear that the study newspaper has consistently adhered to the publication of religious pages by $(88.9 \%)$ while it has not adhered with $(11.1 \%)$ Sixth: The typographic elements used with the religious subjects in the study newspaper:

The following table shows the typographic elements, types and proportions used for religious topics and issues in the study newspaper. 
Table6: It shows the frequency and proportions of the typographic elements used with religious subjects in the study newspaper

\begin{tabular}{|l|l|l|}
\hline$\%$ & $\mathrm{p}$ & typographic elements \\
\hline 28.8 & 61 & Extended address \\
\hline 17.5 & 37 & Wide address \\
\hline 11.3 & 24 & Preface \\
\hline 11.3 & 24 & Photos \\
\hline 9.9 & 21 & Tires \\
\hline 8.5 & 18 & Floors \\
\hline 8.5 & 18 & Title of paragraphs \\
\hline 3.7 & 8 & Secondary Address \\
\hline 0.5 & 1 & Vertical Address \\
\hline 100 & 212 & Total \\
\hline
\end{tabular}

- Increasing number of duplicates due to more than one title per topic

By studying the previous table, it is clear that the extended titles were ranked first by, $(28.8 \%)$, followed by headlines $(17.5 \%)$, introductory titles $(11.3 \%)$, and images with the same proportion (9.9\%), and the flooring parallels with the titles of paragraphs $(8.5 \%)$ each, and secondary titles $(3.7 \%)$, and finally the vertical title $(0.5 \%)$

It discusses the results of the analytical study and recommendations

\section{DISCUSSION OF RESULTS}

The study aimed to identify the general characteristics of the content and form of religious pages in the study paper. The study revealed the size of the area allocated by the newspaper to specialized religious topics, the knowledge of the subcategories of religious issues and topics, the sources used by the newspaper, The stability of the site and the typographic elements used, and in the light of the conclusion of this study highlights the following results:

1. The study showed that the size of the area occupied by the religious subjects in the study paper reached (6\%) among the different subjects dealt with by the newspaper, which is reasonable when compared to the intensity of the issues and topics dealt with by the newspaper, both political subjects and local events hot because of nature The struggle on the land of Palestine, apart from the sports, economic, international and Arab issues, is due to the interest of the newspaper in the religious subjects because of the Islamic religion from the comprehensiveness of the various issues that concern the human, and the newspaper of Palestine conservative newspapers committed to the Islamic vision in the results were consistent with the results of previous studies.

2. The study revealed that the category of judgments and advisory opinions ranked first among the subjects and religious issues dealt with by the study newspaper by about (33\%). This result was agreed with the results of Jawad al-Dalu study. It is important for the reader to answer various questions and queries that need to be judged by religion, while we have found weakness in coverage of other issues of interest to the reader, such as the news of the Islamic world, and the position of religion on the various movements and intellectual currents that have abounded in the Palestinian arena.

3. The study showed that the book category was the first source on which the newspaper relied on various religious topics and issues. It obtained more than 58\% of the various sources. This gives the religious pages a greater strength in terms of their reliance on sources of the newspaper, specializing in Sharia, the fundamentals of religion and the Islamic media.

It is also noted that the percentage of subjects whose source has not been mentioned has reached $8 \%$, which negatively affects these issues.

The study also revealed an absence of a reporter on the religious pages, who cover various religious issues outside the city and the state from which the newspaper is issued, which enriches the religious pages with the news and issues of the Islamic world and the Muslim communities in different Western countries. This is due to the weak financial capacities of the local newspapers, with correspondents outside the state from which the newspaper is published. 
4. The study showed that the daily newspaper Palestine relied on the article in a large extent in dealing with various topics and religious issues, where he received more than (54\%) of the various forms of journalism, due to the adoption of the newspaper on a group of writers specialized in Islamic law and assets Religion, who write various articles periodically to the newspaper, while the study revealed the weakness of the forms and other press arts such as investigative journalism and talk of the press of these two important in the follow-up of some important religious issues or famous Islamic figures and submit to the reader, For the news of the journalist, which prevents the reader from following the news of the Islamic world and its various issues.

5. The study showed that the stability of the publication of religious issues on the pages of the newspaper reached $88.9 \%$, which is a good percentage. However, the rate of instability was about $11 \%$ and is being modified on the tab according to the wishes and preferences of the readers, to reach the stage of stability and stability, which came out by the study of Sharif.

6. The study revealed that the extended titles are the most typographic elements used in the presentation of topics and religious issues in the study paper, where it reached more than (28\%) among the various other elements, because the headlines that extend the most common types of headlines used in printed newspapers, Addresses that are more than one column, and do not reach the width of the page, and the use of other types of addresses reasonably, especially the broad address that reaches the page and demonstrates the importance of the subject, and attracts the reader to it.

The study also revealed the absence of the use of some important typographic elements in attracting the attention of the reader, such as colors that were never used with religious pages. The drawings were not used during the study period, and this is contrary to the results of the previous three studies.

\section{STUDY RECOMMENDATIONS}

Based on the results of the analytical study, and what appeared to the researcher through his living on the subject of the research, it comes out with a set of recommendations that can contribute to the advancement of the study paper in dealing with religious pages specialized form and content, the recommendations are as follows:

- The necessity of dealing with the study paper on various religious issues, especially the intellectual subjects that address the intellectual invasion that seeks to distort the Islamic personality, transform the loyalty of the nation to the West, and interest in Islamic movements and the Islamic world news.

- Not to expand the dissemination of topics of unknown origin, and rely on known sources of good reputation to the reader, because religious topics based on the reader's confidence in the source in the first place.

- The use of all the press arts in presenting religious issues, especially the press, because the press today is a press of news, and the reader seeks to know what is going on in the Islamic world of important events and issues through a summary of relevant news.

- The need to fix the site of religious pages in the newspaper, both in terms of days of publication or page numbers, because of their significant impact in ensuring the maintenance of the specialist reader.

- The use of various means of highlighting religious issues, especially colors, images and floors, because of their ability to attract the attention of the reader, and guide the reader to the most important topics on the page.

\section{REFERENCES}

\section{First: Researches and Studies}

[1] Jawad Al-Dalu, specialized religious press in the Arab world, I 1, Gaza: Dar al-Bashir for printing and publishing, $2017 \mathrm{AD}$.

[2] Hassan Al-Sharif, "Religious Pages in Saudi Newspapers and Magazines: A Comparative Study and Content Analysis", unpublished Master Thesis, Riyadh: College of Advocacy and Information, Imam Muhammad Bin Saud Islamic University, 2018. 
[3] Mohamed Munir Hijab, "The position of the daily newspapers on the issues of religious thought: an analytical study of the newspapers of Al-Ahram, news and republic" unpublished doctoral thesis, Cairo: Faculty of Media, Cairo University, 2017.

\section{Second: Books}

[1] Jawad al-Dalu, the art of modern journalism, I 1, Gaza: Dar al-Bashir, 1995.

[2] Samir Hussein, Media Research Principles and Principles, I 1, Cairo: World of Books, 1976.

[3] Samir Hussein, Content Analysis, I 1, Cairo: World of Books, 1983.

[4] Hassan Makkawi, Laila El Sayed, Communication and Contemporary Theory, I 1, Cairo: The Egyptian Lebanese House, 2006.

[5] Farouk Abu Zeid, the art of journalism, 4, Cairo: World books, 1990

[6] Karam Shalabi, the news story and its Islamic controls, I 2, Jeddah: Dar al-Shorouk, 1988.

[7] Mohammed Abdul Hamid, Content Analysis in Media Research, 1, Jeddah: Dar Al- Shorouk, 1983.

\section{Extension of the Study: Religious Pages in the Palestinian Press}

\section{Content Analysis Form ( $\quad$ ) No.}

\begin{tabular}{|c|c|c|c|c|c|c|c|c|c|c|c|c|c|c|c|c|c|c|c|c|c|c|c|c|}
\hline Typ & ographi & $c$ el & ements & $\begin{array}{l}\text { Site } \\
\text { Cate } \\
y\end{array}$ & egor & $\begin{array}{l}\text { Spa } \\
\text { ce }\end{array}$ & Pres & ss forn & & & & Sour & Irce & & & & Top & & & & & Iss & & \begin{tabular}{|l} 
cate \\
gor \\
y
\end{tabular} \\
\hline $\begin{array}{l}\text { fra } \\
\text { me } \\
s\end{array}$ & \begin{tabular}{|l|l|} 
Gro & col \\
und & our \\
$\mathrm{s}$ & $\mathrm{S}$
\end{tabular} & titl & \begin{tabular}{|l|l} 
Fig & im \\
ure & ag \\
S & es
\end{tabular} & $\begin{array}{l}\text { Not } \\
\text { fixe } \\
\text { d }\end{array}$ & $\begin{array}{l}\text { Fix } \\
\text { ed }\end{array}$ & $\begin{array}{l}\text { cate } \\
\text { gor } \\
y\end{array}$ & $\begin{array}{l}\text { inte } \\
\text { rvie } \\
\text { w }\end{array}$ & $\left|\begin{array}{l}\text { inve } \\
\text { stiga } \\
\text { tion }\end{array}\right|$ & $\begin{array}{l}\text { ne } \\
\text { ws }\end{array}$ & rep & $\begin{array}{l}\operatorname{arti} \\
\text { cle }\end{array}$ & $\begin{array}{l}\text { Sou } \\
\text { rcel } \\
\text { ess }\end{array}$ & $\begin{array}{l}\text { age } \\
\text { nci } \\
\text { es }\end{array}$ & $\begin{array}{l}\text { rep } \\
\text { orte } \\
\text { r }\end{array}$ & age & \begin{tabular}{|l|l}
$\mathrm{B}$ & $\mathrm{O}$ \\
$\mathrm{oo}$ & $\mathrm{h}$ \\
$\mathrm{k}$ & $\mathrm{r}$ \\
\end{tabular} & \begin{tabular}{l|l} 
ot & 1 \\
he & it \\
rs & $t$ \\
t
\end{tabular} & $\begin{array}{l}\text { Isla } \\
\text { mic } \\
\text { thou } \\
\text { ght }\end{array}$ & \begin{tabular}{l|l|} 
Isla & tran \\
mic & sacti \\
call & ons
\end{tabular} & $\begin{array}{l}\text { Wo } \\
\text { rshi } \\
\text { ps }\end{array}$ & $\begin{array}{l}\text { The } \\
\text { Fat } \\
\text { was }\end{array}$ & No & da & NO. \\
\hline & & & & & & & & & & & & & & & & & & & & & & & & 1 \\
\hline & & & & & & & & & & & & & & & & & & & & & & & & 2 \\
\hline & & & & & & & & & & & & & & & & & & & & & & & & 3 \\
\hline & & & & & & & & & & & & & & & & & & & & & & & & 4 \\
\hline & & & & & & & & & & & & & & & & & & & & & & & & 5 \\
\hline & & & & & & & & & & & & & & & & & & & & & & & & 6 \\
\hline & & & & & & & & & & & & & & & & & & & & & & & & 7 \\
\hline & & & & & & & & & & & & & & & & & & & & & & & & 8 \\
\hline & & & & & & & & & & & & & & & & & & & & & & & & 9 \\
\hline & & & & & & & & & & & & & & & & & & & & & & & & 10 \\
\hline & & & & & & & & & & & & & & & & & & & & & & & & 11 \\
\hline
\end{tabular}

Citation: Wael Abdelrazak Almanama. "Religious Pages in the Palestinian Journalism Analytic Study on Felesteen Daily Newspaper". International Journal of Media, Journalism and Mass Communications (IJMJMC), vol 5, no. 2, 2019, pp. 14-22. doi:http://dx.doi.org/10.20431/2455-0043.0502003

Copyright: (C) 2019 Authors. This is an open-access article distributed under the terms of the Creative Commons Attribution License, which permits unrestricted use, distribution, and reproduction in any medium, provided the original author and source are credited. 